\title{
"The unspeakable Calamity this poor Province Suffers from Pyrats": South Carolina and the Golden Age of Piracy
}

\section{Carl E. Swanson}

Cet essai examine l'impact des pirates sur la Caroline du Sud pendant le soi-disant "âge d'or » de la piraterie. Cependant, un examen des prix capturés par les pirates sur la côte de la Caroline démontre que, en dépit de leur réputation colorée, les pirates ont fait peu de dégats au commerce de Charles Town. Bien que les forces navales coloniales aient été généralement faibles, la Caroline du Sud et la Virginie étaient assez fortes pour décourager certains des pirates les plus notoires de l'époque. La piraterie peut avoir infesté la plupart des voies de navigation atlantiques, mais elle a à peine constitué " un âge d'or » sur la côte de la Caroline. L'attention reçue par les pirates en Caroline du Sud pendant les années 1700 - et durant les siècles correspondant - implique que leur impact culturel et politique a dépassé leurs conséquences économiques.

Although the normal hazards of the seas-shoals, uncharted reefs, squalls, lee shores, nor'easters, and hurricanes - regularly posed difficulties for vessels engaged in early eighteenth-century transatlantic commerce, pirates presented the most dramatic dangers. On 22 April 1718, for example, the ship Crawley, commanded by Captain Robert Clark, departed Charles Town, South Carolina, on what proved to be a very short voyage. Loaded with rice, pitch, and tar, the Crawley worked its way toward the open Atlantic homeward bound to London. "As he was just proceeding from the Barr [the sand bar at the entrance to the city's harbor]," an observer later reported, "[he] was unfortunately taken by two Pirates. One a large french Ship Mounted with 40 Guns and the other a Sloop Mounted with 12 Guns with Two other Sloopes for their Tenders having in all about 300 Men all English." The Crawley's fate was not unique, as pirate ships assaulted Charles Town's commerce with seeming impunity: "They [the pirates] are now Come to such a head that there is no Trading in these Parts [.] It being almost Impossible to avoid them."

1 ? to the Board of Trade, 13 June 1718, Records in the British Public Record Office Relating to South Carolina, 1663-1782 (Columbia, SC), VII, 73-75 (microfilm). Hereafter cited as BPRO-SC. The first quotation is on 73; the second is from 75. Blackbeard, perhaps the

The Northern Mariner/le marin du nord, XXI No. 2, (April 2011), 117-142 
This essay examines the impact of piracy on Charles Town's transatlantic commerce during the early eighteenth century, the so-called "golden age" of piracy, 1716 to 1726. During these years, pirates operated on a grand scale and attacked the commerce of numerous Atlantic ports, especially along the North American seaboard, the Caribbean, and the West African coast. Because of the pirates' expansive theaters of operations, piracy offers yet another example of the value of adopting an "Atlantic world view." 2 This essay will place South Carolina's experience with piracy in its Atlantic context. Of course, the golden age pirates did not simply materialize in 1716; commerce raiding by private warships had a lengthy tradition. English New World expansion during the sixteenth century, for example, virtually began with attacks on Spanish shipping. Although London officials did not view such successful predators as Francis Drake, John Hawkins, and Martin Frobisher as pirates, the Spanish certainly did. ${ }^{3}$ During

most notorious eighteenth-century pirate, captured Captain Clark. See Captain Charles Johnson, A General History of the Pyrates, from Their First Rise and Settlement in the Island of Providence, to the Present Time ... (London, 1724), 72. http://digital.lib.ecu.edu/historyfiction/item.aspx?id=joh. Blackbeard eventually released the Crawley, and Captain Clark completed his voyage to London. $\mathrm{He}$ also made three subsequent voyages between London and Charles Town during 1722-1724. See South Carolina Naval Officer Shipping Lists, 1716-1767, from Charles Town (hereafter cited as NOSL), which are housed in the National Archives of Great Britain, London, Colonial Office, 5/508-511, 13 May 1718, 15 March 1722, 9 November 1723, and 14 May 1724. These records are widely available on microfilm, and this study used that format.

2 The literature concerning Atlantic history is expanding at a dizzying rate. For important essays surveying and defining this work see, Alison Games, "Atlantic History: Definitions, Challenges, and Opportunities," American Historical Review CXI (2006), 741-757; Joyce E. Chaplin, "Expansion and Exceptionalism in Early American History," Journal of American History LXXXIX (2003), 1431-1455; David Armitage, "Three Concepts of Atlantic History," in David Armitage and Michael Braddick, eds., The British Atlantic World, 1500-1800 (London, 2002), 11-27; and Nicholas Canny, "Writing Atlantic History; or Reconfiguring the History of Colonial British America," Journal of American History LXXXVI (1999), 10931114. For a wide-ranging discussion concerning perceptions of the Atlantic world produced by literary scholars and historians, see "The 'Trade Gap' in Atlantic Studies: A Forum on Literary and Historical Scholarship," William and Mary Quarterly, 3d Ser., LXV (2008), 135-186. For a longer discussion focusing on Europe and the Americas, see Bernard Bailyn, Atlantic History: Concept and Contours (Cambridge, MA, 2005). For an early, thoughtful example of English Atlantic world history, see Ian K. Steele, The English Atlantic, 16751740: An Exploration of Communication and Community (New York, 1986).

3 Richard Hakluyt, the ardent proponent of English overseas expansion to the New World, advocated the establishment of a commerce raiding base on North America's Atlantic coast in his 1584 tract, "A Discourse concerning Western Planting," in Jack P. Greene, ed., Settlements to Society, 1584-1763 (New York, 1966), 4-8. For early English expansion and commerce raiding see Kenneth R. Andrews's Elizabethan Privateering: English Privateering during the Spanish War, 1585-1603 (Cambridge, 1964); The Spanish Caribbean: Trade and Plunder, 1530-1630 ( New Haven, CT, 1978); and Trade Plunder and Settlement: Maritime Enterprise and the Genesis of the British Empire, 1480-1630 (Cambridge, 1984). 
the seventeenth century English sea captains commanding privately owned warships continued to seize Spanish vessels, especially in the Caribbean. Once again, the Spaniards called their enemies pirates, though the English termed them "buccaneers" because they largely refrained from capturing English vessels and concentrated their actions on the Spanish, England's rivals. ${ }^{4}$ After the English and Spanish governments reconciled their differences concerning New World possessions at the close of the seventeenth century, London officials increasingly viewed seizing ships on the high seas, including Spanish vessels, as piracy and used state power to curb English pirates. ${ }^{5}$ Two imperial wars between England, France, and Spain (King William's War, 1689-1697, and Queen Anne's War, 1702-1713) interrupted peacetime piracy, but scores of private warships seized enemy merchantmen legally during these years. The golden age pirates launched their careers after Queen Anne's War ended, when the Royal Navy contracted and the maritime economy slumped.

Although piracy disrupted trade and caused considerable concern amongst Carolina's government officials and merchants in the early eighteenth century, many accounts have exaggerated its economic impact. ${ }^{6}$ The exploits of such notorious pirates as Blackbeard, Stede Bonnet, Charles Vane, and others have certainly attracted much attention from contemporary chroniclers and subsequent historians. The literature

4 Peter Earle, The Sack of Panama (London, 1981), offers an excellent account of Caribbean buccaneering and the exploits of Sir Henry Morgan, the most famous English buccaneer. Richard S. Dunn comments on the important economic and political roles buccaneers played in seventeenth-century Jamaica; see Sugar and Slaves: The Rise of the Planter Class in the English West Indies, 1624-1713 (Chapel Hill, NC, 1972), chap. 5, 149-187. Mark Gillies Hanna's thoughtful study, "The Pirate Nest: The Impact of Piracy on Newport, Rhode Island, and Charles Town, South Carolina, 1670-1730" (Unpublished Ph.D. dissertation, Harvard University, 2006), also discusses English freebooters from seventeenth-century buccaneers like Morgan to eighteenth-century pirates like Blackbeard. Surprisingly, Hanna's definition of pirates and piracy does not reflect the differences between these freebooters' notions of nationalism or eligible victims. He thinks they were all pirates.

5 Robert C. Richie, Captain Kidd and the War against the Pirates (Cambridge, MA, 1986), is the best book about the English government's changing perception of pirates and of the career of Captain William Kidd. Murky definitions and legal status have not only dogged Atlantic freebooters. Definitions of piracy have also been cloudy for Indian Ocean captains participating in similar activities; see M. N. Pearson, "Corruption and Corsairs in Sixteenth-Century Western India: A Functional Analysis," in Blair B. Kling and M. N. Pearson, eds., The Age of Partnership: Europeans in Asia before Dominion (Honolulu, 1979), 15-41.

6 Historians have measured one important economic impact of piracy: its influence on English ship design. Because of the threat of pirate attack - as well as the danger of enemy warships in wartime-English shipbuilders constructed "defensible ships" that were heavily planked, armed, and manned. These vessels increased the cost of maritime commerce. See Ralph Davis, The Rise of the English Shipping Industry in the Seventeenth and Eighteenth Centuries (London, 1962), chaps. 3-4, 44-80. See also Douglass C. North, "Sources of Productivity Change in Ocean Shipping, 1660-1850," Journal of Political Economy LXXVI (1968), 953-970, and James F. Shepherd and Gary M. Walton, Shipping, Maritime Trade, and the Economic Development of Colonial North America (Cambridge, 1972). 
concerning piracy is vast. ${ }^{7}$ A close examination of the prizes that pirates captured on the Carolina coast, however, suggests that, colorful as they were, pirates did little damage to Charles Town's commerce. Although colonial military and naval forces were generally weak, South Carolina and Virginia were strong enough to deter some of the era's most notorious pirates. Piracy may have plagued most Atlantic shipping lanes, but it hardly enjoyed a "golden age" on the Carolina coast. The attention pirates received in South Carolina during the early 1700 s - and ever since that time - implies that their cultural and political impact exceeded their economic consequences.

Although Blackbeard's most audacious exploits terrorized Charles Town in April 1718, he had earlier taken perhaps as many as three vessels on the Carolina coast in 1717 . In the spring of that year, Blackbeard sailed in company with Captain Benjamin Hornigold from New Providence in the Bahamas to the North American coast and captured en route a "Ship from Madera to South-Carolina, out of which they got Plunder to a considerable Value." 8 Later in the summer in company with Captain Richards, Blackbeard seized two inward bound vessels off Charles Town's bar. ${ }^{9}$ On their second

7 The best place to start is Captain Johnson's A General History of the Pyrates. This eighteenth-century work went through multiple editions and is the single most important primary source. Marcus Rediker has written the best historical accounts of piracy; see Between the Devil and the Deep Blue Sea: Merchant Seamen, Pirates, and the AngloAmerican Maritime World, 1700-1750 (Cambridge, 1987). Though some scholars have criticized this book for its Marxist perspective, Rediker offers numerous insights about why many Anglo-American merchant seamen became pirates. Rediker's Villains of All Nations: Atlantic Pirates in the Golden Age (Boston, 2004) is a thorough examination of piracy's "golden age." David Cordingly's Under the Black Flag: The Romance and the Reality of Life among the Pirates (New York, 1996) offers some thoughtful insights concerning piracy's myths and realities. Peter Earle's The Pirate Wars (New York, 2003) provides a one volume survey of piracy from Elizabethan England to the early nineteenth century. Hanna's "The Pirate Nest" contains useful discussions concerning piracy in eighteenth-century AngloAmerican popular culture; see 334-465. Although aimed at a general audience, scholars can profit from Hugh F. Rankin's The Golden Age of Piracy (New York, 1969). Peter T. Leeson examines the economics of piracy in The Invisible Hook: The Hidden Economics of Pirates (Princeton, NJ, 2009), though he primarily succeeds only in introducing economists' jargon in the study of golden age pirates. Historians have also focused narrowly on the pirates who operated on the Carolina coast; see Shirley Carter Hughson, The Carolina Pirates and Colonial Commerce, 1670-1740 (1894; repr., Spartanburg, SC, 1971); Robert E. Lee, Blackbeard the Pirate: A Reappraisal of His Life and Times (Winston-Salem, NC, 1974); and Lindley S. Butler, Pirates, Privateers, and Rebel Raiders of the Carolina Coast (Chapel Hill, NC, 2000). Hughson exaggerates the impact that pirates exerted on South Carolina's commerce, while Lee's overly glowing reappraisal erroneously depicts Blackbeard as "knight of the black flag," a man who "could have risen to prominence in any profession he selected." See Blackbeard the Pirate, 168 and 38 for the quotations. Butler's account of Blackbeard and Stede Bonnet is more thoughtful and grounded in the sources.

8 Johnson, A General History of the Pyrates, 70.

9 ? to the Board of Trade, 13 June 1718, BPRO-SC, VII, 74. Johnson did not discuss these prizes in A General History of the Pyrates. 
voyage to Carolina, Blackbeard and other freebooters interrupted commerce and exasperated provincial officials, prompting Governor Robert Johnson to request naval support from London. "The unspeakable Calamity this poor Province Suffers from Pyrats Obliges me to inform yor. Lordships of it in Order that his Majestie may know it $\&$ be induced to Afford us the Assistance of a Frigate or two to Cruise hereabouts upon them for we are continually Alarmed \& our Ships taken to the utter ruin of our Trade." 10 Johnson claimed that Blackbeard commanded a flotilla that captured the province's pilot boat and eight or nine vessels. In addition, the pirates made hostages of some of Charles Town's "best Inhabitants" and threatened to kill them if Johnson did not immediately send Blackbeard a chest of medicines. The governor clearly feared the pirates' strength: "This Company is Commanded by one Teach alias Blackbeard [who] has a Ship of 40 od Guns under him and 3 Sloopes [and] Tenders besides \& are in all about 400 Men."11

Johnson was concerned
about the difficulties of ending piracy in Carolina shipping lanes and elsewhere in America. He believed that King George's policy of offering pirates amnesty had failed and contended that only force could eliminate piracy. He feared the situation would get worse because large numbers of pirates operated from New Providence. Johnson knew that London officials had appointed Captain Woodes Rogers governor of the Bahamas with the primary goal to eliminate piracy in what had become the pirates' favorite haunt, but the South Carolina governor was worried. "A Sloope arrived here from [New] Providence about Six Days agoe but I cant learn Capt. Rogers Governr. of those Islands is yet arrived there [;] tis to be hoped he has Frigates with him \& a good force of Land men otherwise he will be under Some resque of being Attact by Pyrats for it being their nest \& rendezvous they will be

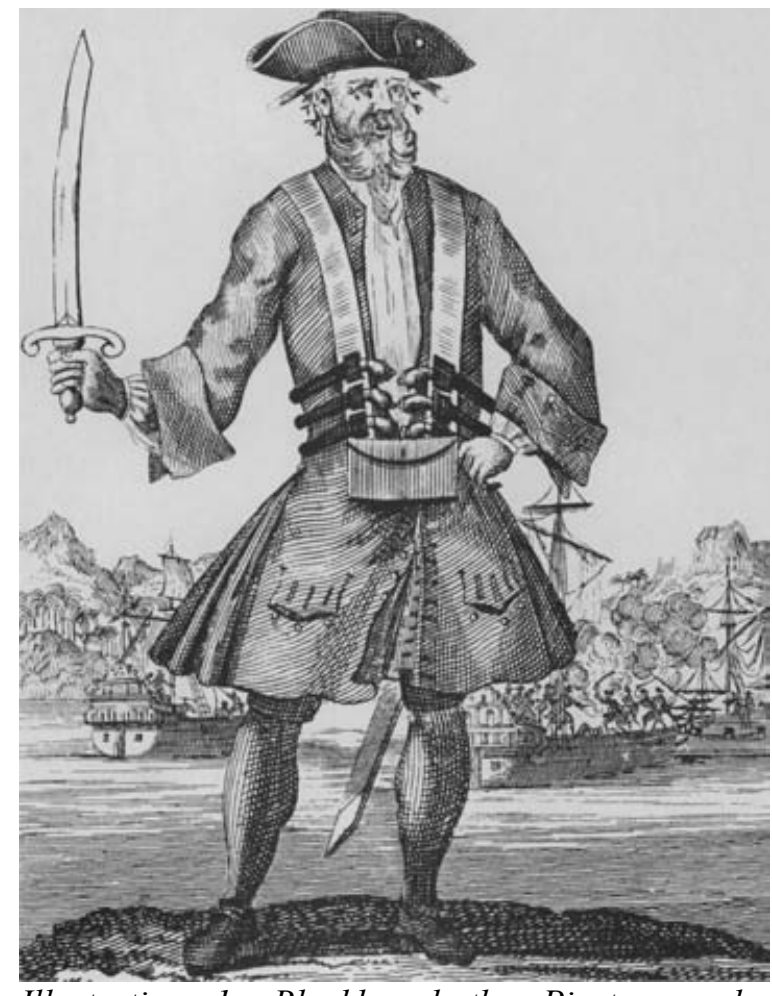

Illustration 1: Blackbeard the Pirate, as he appeared in the second edition of Capt. Charles Johnson, A General History of the Pyrates, from Their first Rise and Settlement in the Island of Providence, to the Present Time. ... The second Edition with considerable Additions. London: printed for, and sold by T. Warner, 1724.

10 Johnson to the Board of Trade, 18 June 1718, BPRO-SC, VII, 134.

11 Ibid. See also Johnson, A General History of the Pyrates, 72-74, and Butler, Pirates, Privateers, and Rebel Raiders, chap. 2, 25-50. 
unwilling to have the place Settled."12 Blackbeard's 1718 foray was the most dramatic piratical incursion on South Carolina's coast, but it was certainly not the last.

In fact, just a few months after Blackbeard had departed, two pirate ships commanded by Captain Charles Vane and Captain Yeats "lay on the Barr of this Harbour"

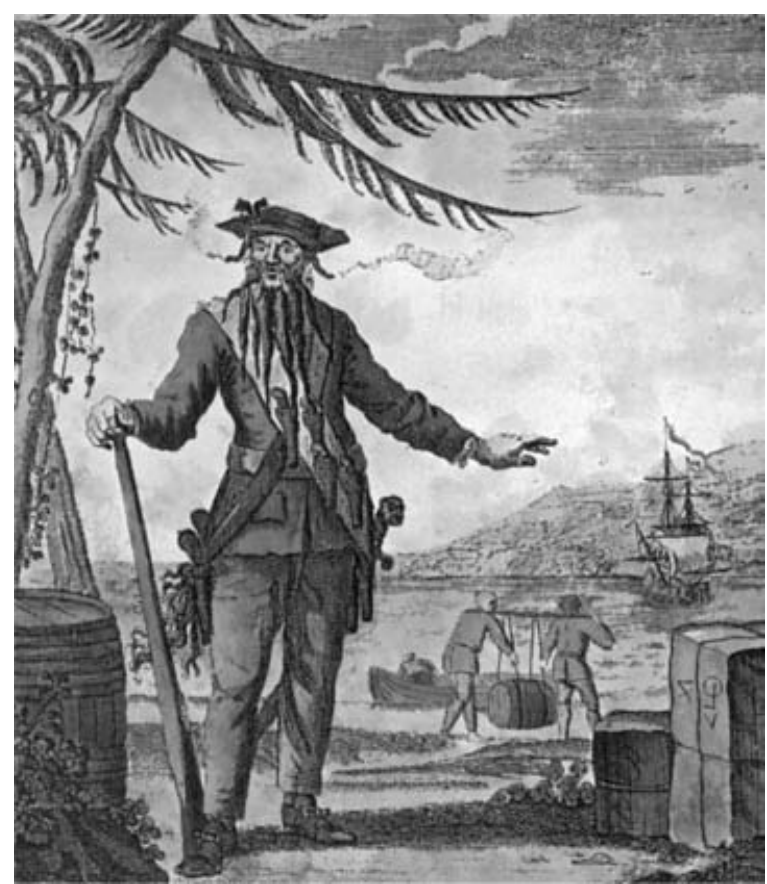

Illustration 2: Captain Teach, commonly call'd Black Beard, appeared more sinister in a later edition of Capt. Charles Johnson, A General History of the Lives and Adventures of the most Famous Highwaymen, Murderers, Street-Robbers, \&c. To which Is Added, a Genuine Account of the Voyages and Plunders of the most Notorious Pyrates. London: printed for and sold by J. Janeway, in White-Fryers, 1734. and disrupted Carolina commerce in August $1718 .^{13}$ The pirates attacked one ship and two sloops inward bound and assaulted four outwardbound vessels. As upsetting as these actions were to Governor Johnson, he had additional worries because he had received intelligence that yet another pirate vessel was careening and refitting in North Carolina and could soon be expected off Charles Town's bar. Vane's attacks and the fear of another pirate ship's arrival prompted Johnson to commission Colonel William Rhett to fit out two eight-gun sloops to apprehend Vane's pirates. Rhett was a Charles Town merchant, multiple office holder, and one of colonial South Carolina's most colorful characters, as will be seen. He had also successfully commanded the provincial vessels that defeated a French and Spanish invasion of South Carolina during Queen Anne's War. ${ }^{14}$ The Henry, commanded by Captain John Masters, with a crew of seventy men, and the Sea Nymph, commanded by Captain Fayer Hall, with sixty men,

12 Johnson to the Board of Trade, 18 June 1718, BPRO-SC, VII, 136. The Board of Trade read Johnson's letter on 28 August 1718, and directed its secretary, William Popple, to send a copy of the letter to the Lords Commissioners of the Admiralty, which Popple did the same day. See Popple to Josiah Burchett, 28 August 1718, ibid., VII, 151. Burchett was the secretary to the Admiralty.

13 Governor Robert Johnson \& Council to the Board of Trade, 21 October 1718, ibid., VII, 164. See Johnson, A General History of the Pyrates, 97-98.

14 "An Impartial Narrative of ye Late Invasion of So. Carolina by ye French \& Spaniards, in the Month [of] August 1706," referred to in Lord Cornbury to the Board of Trade, 3 October 1706, BPRO-SC, V, 171-187. 
set sail under Rhett's general command, who made the Henry his flagship. ${ }^{15}$

Rhett's force sailed south in search of Vane's men, but to no avail. The sloops then headed north to Cape Fear to intercept the pirates who were refitting in that North Carolina river. Rhett's quarry turned out to be the notorious pirate Major Stede Bonnet and his crew of fifty men. ${ }^{16}$ Charles Town residents were well acquainted with Bonnet because he had paid a visit to the South Carolina port in August 1717. On that occasion, Bonnet, known as the "gentleman pirate," seized a sloop and a brig bound for Charles Town before sailing to North Carolina to join Blackbeard's pirate fleet. ${ }^{17}$ In the ensuing battle both South Carolina sloops and Bonnet's vessel ran aground, and the pirates fired

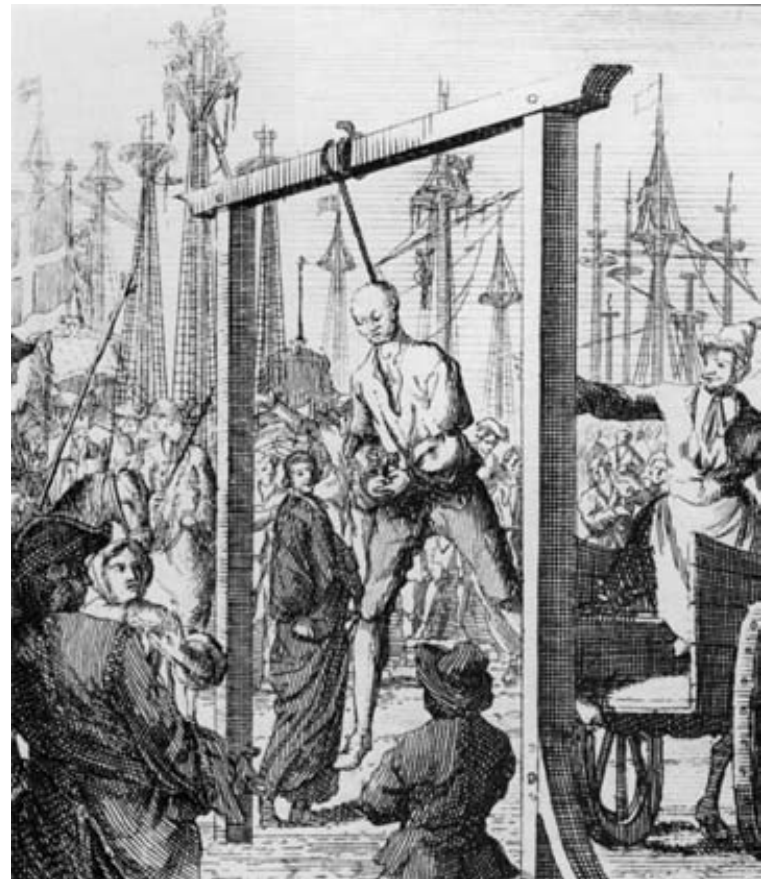

Illustration 3: The hanging of Major Stede Bonnet. This engraving was published in Charles Johnson's A General History of the Pyrates.

effectively into the Henry from close range. Fortunately for Rhett, the Henry got off first and bore down on the pirates, which prompted them to surrender "on Collo. Rhett's Promising he would intercede for Mercy." 18 This bloody engagement cost Rhett's force fourteen killed and sixteen wounded. The pirates lost nine men killed and three wounded. Rhett's intercession on behalf of Bonnet and his crew was ineffective, because Charles Town officials subsequently hanged the "gentleman pirate" and his men. ${ }^{19}$

15 Johnson, A General History of the Pyrates, 97. See also Butler, Pirates, Privateers, and Rebel Raiders, 54-65.

16 Bonnet's exploits have attracted much attention. See, Johnson, A General History of the Pyrates, chap. 4, 91-112; and Butler, Pirates, Privateers, and Rebel Raiders, chap. 3, 51-72. Governor Johnson \& Council to the Board of Trade, 21 October 1718, BPRO-SC, VII, 164, provides the number of Bonnet's crew.

17 Johnson called Bonnet a "Gentleman of good Reputation in the Island of Barbadoes," where he was a sugar planter. Unlike most pirates, Bonnet did not capture his sloop, the Revenge; he bought it and paid for its outfit. See A General History of the Pyrates, 91.

18 Johnson \& Council to the Board of Trade, 21 October 1718, BPRO-SC, VII, 165. British North America's only newspaper, the Boston News-Letter, reported the engagement between Rhett's forces and Bonnet's pirates in its issue for 29 December 1718.

19 Captain Johnson and Butler present slightly different casualty figures from those presented here, which result from Governor Johnson's report to the Board of Trade. Johnson provides substantial coverage of Bonnet's trial, including the lengthy sentencing speech delivered by 
Although South Carolina's forces had successfully eliminated Bonnet as a pirate threat, Governor Johnson was still concerned. "This Undertaking, besides that it has been a Considerable Expence to Us Will (Wee Apprehend) very much Irretate the Pirates who Infest this Coast in great Numbers." Johnson pleaded with the Board of Trade to lay before the king "the great Danger Our Trade \& Collony are in from them [the pirates], They having at some times Blocked up Our Harbour for Eight or Ten Days together, and taken all that come in or go out." Johnson desperately wanted the Admiralty to dispatch a Royal Navy warship to patrol the Carolina coast. ${ }^{20}$

Johnson proved to be prophetic, as he informed the Board of Trade just two months later. After reminding the London officials of his fears of future pirate attacks in retaliation for Rhett's expedition, Johnson wrote, "These Our Apprehensions have proved too true, Wee having been blocked up, and several Ships taken in Sight of the Town." 21 Perhaps motivated by Rhett's earlier success, Johnson himself commanded a force of "Several Ships \& vessells" and sailed in quest of the pirates. Once again, South Carolina forces soundly defeated their opponents. The governor's forces encountered a sloop and a ship off the Carolina coast almost in sight of Charles Town. After firing a broadside, Johnson's men boarded the pirate sloop. The pirates put up a vigorous fight and did not surrender until after their captain had been killed and only a few crew members remained alive, most of whom were seriously wounded. The South Carolinians also captured the ship and took many prisoners. It was not until the action was concluded that Governor Johnson learned that he had captured the pirate sloop New York Revenge and had killed its commander, Captain Richard Worley, a notorious pirate who had terrorized the New York and Pennsylvania coasts. Worley's pirates had captured the ship Eagle Galley off the Virginia capes and fitted it out as a pirate vessel, which they renamed the New York Revenge's Revenge. After returning to Charles Town, the authorities hastily called the province's vice-admiralty court into session because most of the prisoners had suffered serious wounds, and provincial officials wanted to try, convict, and execute the pirates before they succumbed to their injuries. The trials began on 19 November 1718, and on 24th, the pirates were convicted and executed at White Point. ${ }^{22}$ Despite this success,

SC Vice-Admiralty Judge Nicholas Trott, who was also the province's chief justice as well as Rhett's brother-in-law. See Johnson, A General History of the Pyrates, 107-112.

20 Johnson \& Council to the Board of Trade, 21 October 1718, BPRO-SC, VII, 165.

21 Johnson \& Council to the Board of Trade, 12 December 1718, ibid., VII, 167.

22 Hughson, The Carolina Pirates and Colonial Commerce, 118-122. Considerable confusion exists concerning Governor Johnson's engagement with Worley's crew. Johnson's A General History of the Pyrates placed the engagement near Jamestown, Virginia, not Charles Town. He also stated that the Carolinians killed all the pirates except Worley and one other man, both of whom were desperately wounded. The day after the engagement Captain Johnson wrote that the Governor Johnson ordered Worley and the other surviving pirates to be taken ashore where "they were both hanged up, for fear they should dye, and evade the Punishment as was thought due to their Crimes." See A General History of the Pyrates, 344-346. The quotation is from 346. Interestingly, Governor Johnson did not mention these executions in his report to the Board of Trade. Captain Johnson's date of execution, 17 February 1719, is clearly incorrect, since the trials took place in November 1718, and Governor Johnson wrote 
Johnson reiterated his request for Royal Navy protection. To strengthen his appeal, he emphasized South Carolina's value to the king's navy because of its substantial naval stores exports. ${ }^{23}$

The successful operations commanded by Rhett and Johnson largely ended pirate attacks on the Carolina coast in the early eighteenth century. At least that is the view from the province's governors. Johnson wrote no more letters complaining about piracy to London officials, and neither did Francis Nicholson, his successor. Imperial administrators eventually decided to send a Royal Navy frigate to pursue pirates in South Carolina sea-lanes, but that decision occurred in April 1719, months after the pirates ceased to be a problem. ${ }^{24}$

Two pirates did make subsequent visits to the South Carolina coast. These operations

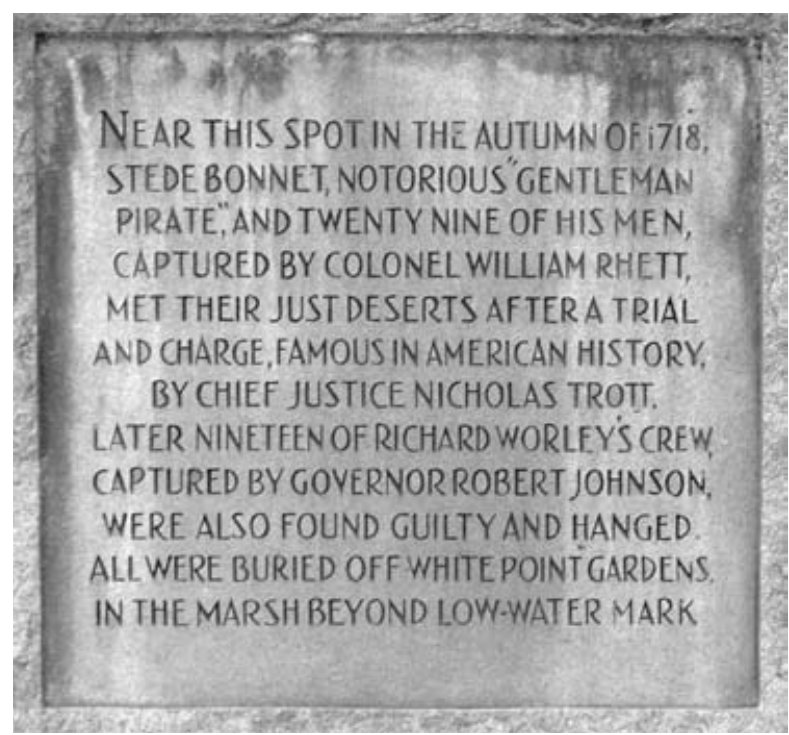

Illustration 4: Historical Marker Commemorating Pirate Executions, White Point Gardens, Charleston, South Carolina. Photographed by the author, 28 April 2011. were fleeting and on a much smaller scale than earlier incursions. As a result, Governor Nicholson did not even mention these events to London officials. In June 1722, Captain George Lowther cruised off Charles Town and attempted to capture the ship Amy as it headed for Europe. Instead of striking the colors and surrendering to the pirates, Captain Gwatkins, the Amy's master, engaged the pirates and forced Lowther's vessel to run aground. The Amy then bore down on the pirates, but after a shot from the freebooters killed Captain Gwatkins, the $A m y$ 's crew lost heart and sailed away. Lowther was finally able to get off and sailed to a secluded North Carolina inlet to refit, where he "staid a long while before he was able to put to Sea again." ${ }^{25}$ Thus, pirates received another setback on the Carolina coast.

Captain Edward "Ned" Low enjoyed better success the next spring. Commanding the schooner Fancy, of eighty tons, ten guns, and eighty men, Low sailed in consort with the brigantine Ranger, commanded by Captain Charles Harris. Off the Carolina coast on 27 May, Low and Harris seized four vessels that had departed Charles Town two days previously: the ships Crown, King William, Carteret, and a brigantine.

his account of the engagement in December 1718. The Board of Trade did not receive this report until February 1719; perhaps this accounts for one of Captain Johnson's errors. 


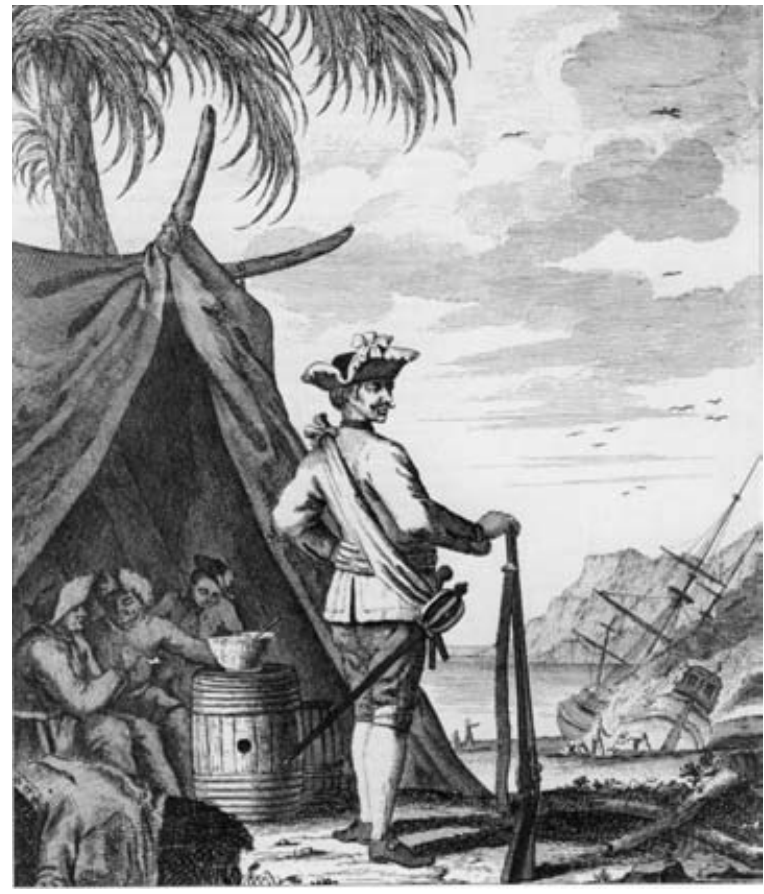

Illustration 5: Capt. George LowTHer and his Company at Port Mayo in the Gulph of Matique from Capt. Charles Johnson, A General History, op. cit., 1734.
The pirates probably plundered these vessels and let them go because they were after other prizes a few days later. $^{26}$ By early June, Low and Harris had captured eight more vessels, including two brigantines bound for England from Carolina. The pirates experienced bad luck on 10 June when they mistook HMS Greyhound, commanded by Captain Peter Solgard, for a merchantman. After a long and bloody engagement, the Greyhound captured the Ranger, but Low escaped. He continued to seize numerous British, French, and Portuguese vessels, though apparently none involved in the Carolina trade. ${ }^{27}$

Clearly, piracy posed a serious threat to Charles Town's Atlantic trade. Flamboyant freebooters seized vessels, plundered cargoes, and forced, cajoled, or welcomed mariners to join their

piratical crews. Assessing the pirates' economic impact is more complicated, however. Writing in the 1720s, Captain Charles Johnson, who produced the most valuable and reliable eighteenth-century books about piracy, asserted that pirates had dealt British trade a serious blow indeed. Johnson believed that pirates captured more British vessels than the combined force of French and Spanish naval warships and privateers during Queen Anne's War: "As the Pyrates in the West-Indies have been so formidable and numerous, that they have interrupted the Trade of Europe into those Parts; and our English Merchants, in particular, have suffered more by their Depredations, than by the

Ibid., 379.

27 Ibid., 380-390. Johnson provided no information concerning Low's ultimate fate, saying only that rumors placed him sailing to Brazil, but no certain information had arrived in England. A subsequent edition of this work provided no further clues about Low. See $A$ General History of the Lives and Adventures of the Most Famous Highwaymen, Murderers, Street-Robbers, \&c. To Which Is Added, a Genuine Account of the Voyages and Plunders of the Most Notorious Pyrates. ... (London, 1734), 272, Eighteenth Century Collections Online. Gale Group. http://galenet.galegroup.com.jproxy.lib.ecu.edu/servlet/ECCO. Rediker reports that Low's crew rebelled against his violent régime and threw Low and his closest supporters in a small boat in the open ocean without provisions to meet their fate. A French ship rescued Low, but he subsequently suffered execution for his crimes. See Rediker, Villains of All Nations, 171-172. 
united Force of France and Spain, in the late War."28 But was Johnson right?

Historian Marcus Rediker has offered perhaps the most thoughtful evaluation of Johnson's claim. Using historian Ralph Davis's estimates, Rediker points out that Britain lost about two thousand vessels to the French and Spanish during Queen Anne's War. Although British predators captured at least as many enemy prizes, Rediker concluded that "[b]y this equation, there can be no doubt that Johnson was right." 29 Rediker has supported his contention with persuasive evidence. First, he estimated that pirates captured and plundered about 2,400 vessels. Although he realized that most of these vessels were not total losses, British warships did not capture a similar number of pirate vessels to balance these prizes.

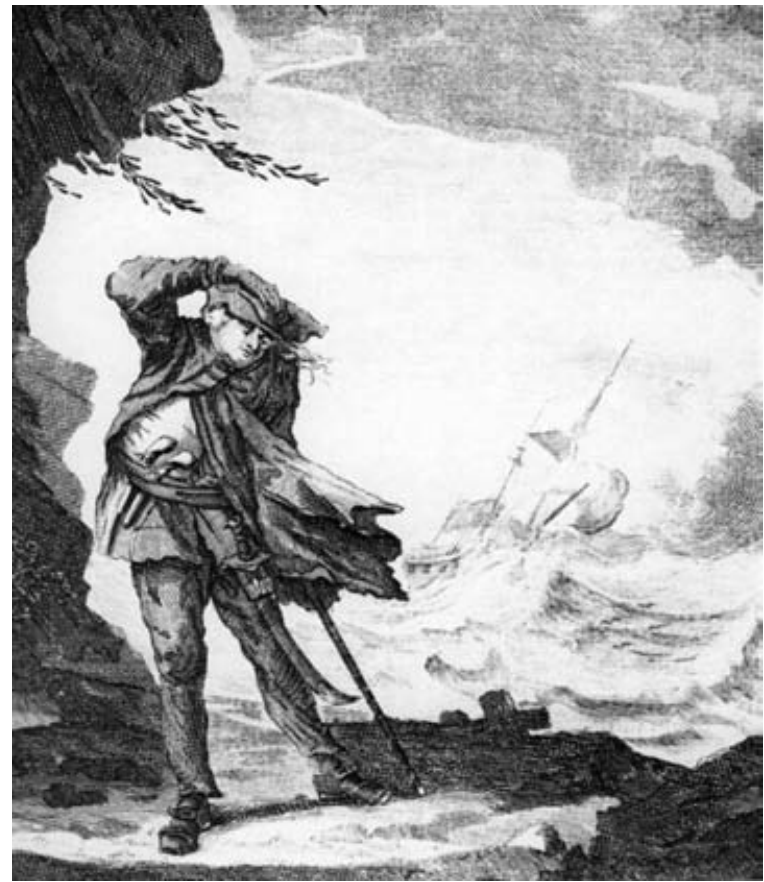

Illustration 6: Cap ${ }^{\mathrm{t}}$. EDwARD Low in $\mathrm{y}^{\mathrm{e}}$ Hurricane which he and all the Crew had Like to perish from Capt. Charles Johnson, A General History, op. cit., 1734 .

Second, many pirates sank or burned their captures, which certainly dealt a serious blow to British shipping. Rediker has also compiled a sample of 545 vessels taken by pirates between 1716 and 1726, the peak years of piracy's "golden age." The most active years for captures in this sample were $1717,1718,1720$, and 1722, with a rapid decline after 1724 - a pattern consistent with most evidence from piracy in the golden age. Moreover, the years with the greatest number of pirates hanged were 1718 (110) and 1722 (148). In Rediker's sample 11 percent of the vessels were "severely damaged or destroyed." If the estimated 2,400 vessels captured suffered a similar fate, Rediker concluded, "The merchants and officials knew whereof they spoke when they complained about the 'infestation' of pirates and the tremendous damage they did to trade." 30

Rediker corroborated Johnson's contention that pirates disrupted British maritime trade more than a major imperial conflict, but he focused on piracy throughout the Atlantic world. Do his conclusions apply specifically to South Carolina? Rediker

28 Johnson, A General History of the Pyrates, 17. On the value and reliability of Johnson's book, see Rediker, Villains of All Nations, 180, and Cordingly, Under the Black Flag, xix-xx. Hanna, "The Pirate Nest," is less convinced about Johnson's veracity. He believes that Daniel Defoe actually wrote this work and that it contains many fictional passages. See chaps. 10 and 11, 372-465.

29 Rediker, Villains of All Nations, 33.

30 Ibid., 34-35. The quotation is on 35. 
correctly believed that pirates intercepted more vessels off the Carolina Coast than French and Spanish warships; or at least that is how South Carolina officials viewed the situation. There are no reports of French and Spanish warships seizing merchantmen bound to or from Charles Town in the correspondence between South Carolina and London officials.

Although the French and Spanish did not intercept Carolina merchantmen, they did try to invade South Carolina. In 1706, a fleet of five private men of war carrying an estimated 800 men sailed up to the "Barr" of Charles Town at the entrance to the city's harbor. The governor of Havana assisted the French privateers commanded by Captain Le Feboure by providing men, supplies, and information. The governor believed Charles Town was vulnerable because of a raging sickness that would deter country militiamen from entering the city to defend the port. The flotilla departed Havana and headed to St. Augustine, Florida, where it picked up more men and supplies. ${ }^{31}$

Fortunately for South Carolinians, Captain Peter Stool, commander of the New York privateer sloop Flying Horse, encountered this force off St. Augustine and sailed immediately for Charles Town to warn South Carolina officials. The warning came just in time, as signal fires from Sullivan's Island announced the enemy's arrival only an hour after Stool met with provincial authorities. After sailing up to the bar and reconnoitering the area, the enemy sent a messenger to demand the town's surrender, but Governor Sir Nathaniel Johnson refused. The French and Spanish then landed men on James Island and on the land between the Wando River and Sullivan's Island (present day Mount Pleasant), where they burned houses and destroyed livestock. Provincial militia units eventually captured many of these enemy invaders. ${ }^{32}$

South Carolina also mounted a naval force to repel the enemy's flotilla. Colonel Rhett commanded the colony's forces, which consisted of three ships, two sloops, and a fire ship. The owners of these private vessels volunteered their use to defend the province. They included Captain Stool's privateer and the Mermaid Galley, owned and commanded by North Carolina Governor Thomas Cary, who happened to be in town on private business. Rhett's forces sailed toward the enemy vessels on 31 August, but the French and Spanish, having the advantage of wind and tide, escaped. Two days later Rhett and Stool sailed over the bar in the two sloops and headed for Sewee Bay, after receiving information that a French ship had anchored there to support the land forces. Rhett and Stool won a complete victory the next day, capturing the French ship and the eighty to ninety man crew. This largely ended the invasion. The French and Spanish lost more than 300 men killed, wounded, and captured. ${ }^{33}$ The author of the "Impartial Narrative," which London officials read in December 1706, thought this was a victory of epic proportions: "And thus through the Providence of Almighty God the Malicious designs of or. Enemies are defeated and their Fleet like a Second Spanish Armada who

"An Impartial Narrative of ye Late Invasion of So. Carolina by ye French \& Spaniards, in the Month [of] August 1706," referred to in Lord Cornbury to the Board of Trade, 3 October 1706, BPRO-SC, V, 171-172.

33 Ibid., V, 182-187. 
had she Succeeded intended nothing more than the utter ruine and destruction of the flourishing Collony." ${ }^{\prime 34}$

The 1706 French and Spanish invasion force of five warships and 800 men was more powerful than any of the pirate fleets that infested South Carolina's shipping lanes during the golden age. Blackbeard's ships in 1718, the largest pirate fleet, carried half as many men. Although the French and Spanish did little damage and captured no vessels before they were defeated, given the number of enemy ships and men, the threat was very real. If the commanders of the 1706 invasion force had been more effective, Captain Johnson's claims that pirates posed a more serious threat would be much less persuasive.

Several factors suggest that pirates exerted a less serious impact on Carolina commerce than on the trade of other British ports. First, instead of enduring a golden age of piracy, Charles Town basically suffered a golden eighteen months. Nearly 70 percent of all pirate attacks occurred between the spring of 1717 and the fall of 1718. Blackbeard and his consort, Captain Richards, seized two inbound vessels off the Charles Town bar in the summer of 1717, while Stede Bonnet and his crew captured a sloop and a brigantine in August of the same year. Both pirate companies then sailed farther north without capturing additional vessels. ${ }^{35}$ These incursions did not provoke widespread fear and numerous complaints to London from South Carolina officials; those came a year later. In 1718, pirate ships commanded by Blackbeard, Richards, Vane, and Worley attacked Carolina shipping, prompting the provincial government to launch two expeditions that proved to be successful. Rhett captured Bonnet's crew, and Johnson killed Worley and captured or killed all his men.

Other missions against pirates who had raided South Carolina commerce were similarly successful in 1718. Acting on the orders of Virginia Lieutenant Governor Alexander Spotswood, a Royal Navy force, commanded by Lieutenant Robert Maynard, defeated and killed Blackbeard at Ocracoke, North Carolina, on 22 November 1718. ${ }^{36}$ Captain Vane suffered a fate similar to Bonnet's in early 1719. An old acquaintance apprehended Vane, whose vessel wrecked on an uninhabited Caribbean island, and transported him in irons to Jamaica, "at which Place he was try'd, convicted, and executed." ${ }^{37}$ Thus, the most famous pirates who had assaulted Charles Town shipping died in battle or suffered execution by early 1719. There are no reports of piratical activities in Rediker's peak year of 1720. While in 1722, another peak year, Captain Lowther's pirate crew failed to take the Amy and were themselves nearly captured. South Carolina officials did not write to the Board of Trade concerning every vessel lost to pirates. Captain Low's successes in 1723, for example, did not prompt a single letter. It is likely, however, that if pirates had "infested" the Carolina coast in those other years,

34 Ibid., V, 185.

35 ? to the Board of Trade, 13 June 1718, BPRO-SC, VII, 73-74; Johnson, A General History of the Pyrates, 92.

36 Boston News-Letter, 23 February 1719; Johnson, A General History of the Pyrates, 78-86; Butler, Pirates, Privateers, and Rebel Raiders, 45-47; Cordingly, Under the Black Flag, 194201; Earle, Pirate Wars, 193-194.

37 Johnson, A General History of the Pyrates, 147-149. The quotation is on 149. 


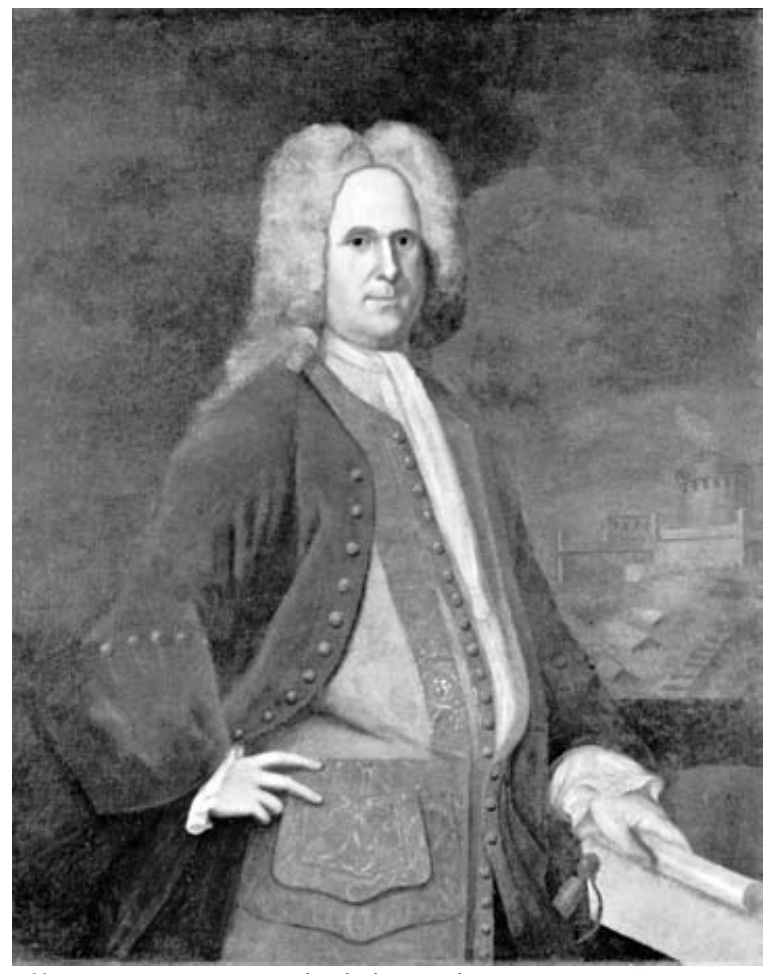

Illustration 7: Virginia Lieutenant Governor Alexander Spotswood, by Charles Bridges. Original in Governor's Palace, Colonial Williamsburg, Virginia.
Charles Town officials would have complained to London. Thus, piracy plagued South Carolina's shipping for a much briefer period than in the larger Atlantic world.

In addition, pirates operating in Carolina sea-lanes did not capture many prizes and they sank or burned even fewer of the vessels they did take, which reduced the economic impact of their captures. Table 1 (page 141) lists the prizes captured off the Carolina coast. Blackbeard and his associates seized only three vessels in 1717 , and they may have released all three of them. (See Table 1.) Blackbeard and his crew were more disruptive the next year when they closed down the port and held the city for ransom. Even so, they departed after seizing only four vessels, all of which they released. They did not burn or sink a single merchantman, nor did they kill anyone in their attacks. The pirates also released all of their hostages. ${ }^{38}$

Bonnet was more destructive, burning half of the prizes his crew seized, but they only captured two vessels, and Rhett's force captured the "gentleman pirate" before he could intercept additional merchantmen.

Captain Vane's pirate crew captured seven vessels but probably did not destroy any of them. The fate of one is uncertain. On the other hand, he released his most valuable prize, and the owners eventually regained their lost cargo. Vane seized the London-owned Dorothy, William Thompson master, as the brigantine neared Charles Town bound from Africa with a cargo of slaves. Vane took the slaves out of the Dorothy and put them on board his consort, a sloop commanded by Captain Yeats. Vane then released the Dorothy, which Thompson sailed safely to Charles Town. Vane and his men did not profit from their actions, however. It seems that Yeats was tired of his life as a pirate: "For Yeats having often attempted to quit this Course of Life, took an Opportunity

38 Butler, Pirates, Privateers, and Rebel Raiders, 49. There are differing accounts concerning Blackbeard's captures. South Carolina Governor Johnson claimed the total was eight or nine vessels; see Johnson to the Board of Trade, 18 June 1718, BPRO-SC, VII, 134. Captain Johnson's more detailed account put the number of prizes at four; see Johnson, A General History of the Pyrates, 72. 
in the Night, to leave Vane and to run into North-Edisto River, to the Southward of Charles-Town, and surrendered to his Majesty's Pardon. The Owners got their Negroes, and Yeats and his Men had Certificates given them from the Government." ${ }^{39}$ After failing to prevent Yeats from sailing off with the Dorothy's slaves, Vane cruised off Charles Town's bar and took two ships homeward bound for England. Vane released one of these prizes and maybe the other as well before heading north, where he rendezvoused with Blackbeard in North Carolina. ${ }^{40}$ Vane did not intercept any other vessels bound to or from Charles Town, and as mentioned, was captured himself in 1719.

Two other pirates operating off the Carolina coast enjoyed even fewer successes. Captain Worley took several ships in sight of Charles Town before succumbing to Governor Johnson's expedition. The disposition of Worley's prizes and their cargoes is unknown, but the authorities probably recovered them. ${ }^{41}$ Captain "Calico" Jack Rackham also captured a ship homeward bound from Charles Town to England in February 1719. Rackham had experience cruising off the Carolina coast, as he had formerly served as quartermaster on Vane's pirate ship. Rackham replaced Vane as the captain in November 1718 after Vane had displayed signs of cowardice in an engagement with a French man of war. Like Worley, however, Rackham and his men reaped few profits from their prize. He took the prize ship to the Bahamas where Woodes Rogers, the anti-pirate governor of those islands, recaptured the vessel. After experiencing indifferent success in the Caribbean during the rest of 1719 and the first half of 1720, Rackham's luck ran out. Sir Nicholas Lawes, Jamaica's governor, learned that Rackham's crew had harassed the island's trade, so he dispatched an armed sloop that captured the pirates. Colonial authorities executed Calico Jack and his men for piracy in Port Royal, Jamaica, in November $1720 .^{42}$

Table 1 (page 141) demonstrates that the "golden age" of piracy inflicted little damage on South Carolina's shipping. Government officials counted twenty-three vessels captured by pirates, plus "several" others seized by Captain Worley. The pirates released or government officials recaptured seventeen of these vessels. Others were probably recovered, especially Worley's prizes. It is impossible to determine the value of the cargoes "plundered" by the pirates, but most goods likely remained on the prizes. Outward-bound vessels laden with barrels of rice and naval stores were hardly enticing booty. European textiles, hardware, and other manufactured goods bound from England for South Carolina were scarcely more attractive plunder.

Another factor limited the pirates' plunder in Carolina shipping lanes: they cruised during the wrong season. Pirates generally did not plan their voyages to take advantage of seasonal shipping patterns. Historian David Cordingly thinks pirates engaged in very little seasonal planning: "Apart from the obvious desire to avoid the North Atlantic in winter, and a sensible use of the trade winds when crossing the Atlantic,

39 Johnson, A General History of the Pyrates, 98. The NOSL include the Dorothy's entrance into Charles Town.

40 Johnson, A General History of the Pyrates, 144-145.

41 Governor and Council to the Board of Trade, 12 December 1718, BPRO-SC, VII, 167.

42 Johnson, A General History of the Pyrates, 150-154. 
there was no consistency in the planning and execution of most voyages. Indeed, there was very little forward planning by any of the pirate crews ... A study of the tracks of the pirate ships shows many of them zigzagging all over the place without apparent reason." ${ }^{43}$ Pirate activity off the Carolina coast largely supports Cordingly's contention. To maximize their chances of capturing prizes, pirates should have operated off Charles Town during the busiest time of the shipping year-the winter and spring. The annual cycle of growing and processing rice largely dictated the Carolina shipping season. New rice came to market in the late fall, seldom before November, and the volume of shipping normally picked up in the winter and spring. Merchants had shipped most of the crop by May, and business declined in the summer and fall. These slack months also coincided with the dangerous hurricane season.

Few pirates arrived off Charles Town's bar at the "right" time of the year, when the highest volume of shipping was liable for capture, as Table 2 (page 142) demonstrates. Blackbeard was an exception and timed his 1717 and 1718 voyages perfectly, arriving in the spring both years. He sailed away in late April or early May in 1718 and headed to North Carolina. In June, he was cruising off Bermuda before returning to North Carolina, where he met his end in November. Ned Low also arrived off the coast in a timely fashion in late May 1723 and captured four prizes. Stede Bonnet arrived in Carolina shipping lanes in August 1717 during the slow summer season and sailed away after taking two vessels, never to return. Captains Vane and Yeats arrived in late August 1718. After Yeats surrendered to South Carolina authorities, Vane sailed north and visited Blackbeard in September before heading farther north at the beginning of October. Captain Worley arrived even later in the fall of 1718. Like Blackbeard and Low, Jack Rackham demonstrated better timing when he captured a ship bound from Charles Town to England in February 1719. Although he actually captured the prize near Bermuda, and not on the South Carolina coast, Rackham's success occurred during a busier shipping month, when pirates were more likely to encounter prizes. Captain Lowther's timing was correct in 1722 when he arrived in late May or early June, but his underestimation of the Amy negated his timely arrival. Fortunately for Charles Town merchants and their British business associates, pirates did not time their voyages to coincide with South Carolina's busiest shipping months. In the subsequent imperial wars of the 1740s, Charles Town's businessmen would not be so lucky. Spanish and French privateers apparently knew more about the shipping seasons and timed their voyages for Charles Town's busiest months of the year. ${ }^{44}$

It is likely that pirate attacks had little impact on marine insurance premiums, although that form of enterprise was far from fully developed during piracy's "golden age." Lloyd's Coffee House in Lombard Street in the City of London attracted merchant underwriters from the early 1690s, but Lloyd's List did not begin publication until 1734, and Lloyd's Register, its successor, did not appear until 1764-1766. The origins of present day Lloyd's of London came even later, when a loose group of merchants organized in

43 Cordingly, Under the Black Flag, 89-90.

44 Carl E. Swanson, Predators and Prizes: American Privateering and Imperial Warfare, 1739-1748 (Columbia, SC, 1991), 164-171. 
1774 at the New Lloyd's at the Royal Exchange. As a result, many vessels bound to British, foreign, and British colonial destinations sailed without insurance. ${ }^{45}$ Although the marine insurance business was underdeveloped during the early eighteenth century, it actually expanded during the very years that Atlantic pirates were at their most active. Parliament established two new chartered companies - the Royal Exchange Assurance Company and the London Assurance Company-in 1720, and the capital invested in marine insurance increased throughout the decade. At the same time premiums fell while coverage increased. ${ }^{46}$ The expansion of British marine insurance during the most active period of Atlantic piracy suggests that the pirates' economic impact has been overstated. Later in the century the actions of Spanish and French warships and privateers exerted a marked impact on British marine insurance premiums. Vessels sailing between Britain and the North American and West Indian colonies faced dramatic premium increases. ${ }^{47}$

Pirates caused little serious economic damage to Charles Town's Atlantic commerce, yet they attracted considerable attention during the 1700s and possibly even more during subsequent centuries. How can this be explained? Part of the reason is cultural. Bold, swashbuckling pirates have captured the public imagination since at least the seventeenth century. Certainly, the European reading public devoured Alexander O. Exquemelin's tales of New World buccaneers in his De Americaeneche Zee Roovers. Originally published in Amsterdam in 1678, French, Spanish, and German translations soon followed. It appeared in English as Bucaniers of America in 1684. ${ }^{48}$ Captain Johnson's A General History of the Pyrates enjoyed similar success, going through several editions during the 1720s and 1730s. Pirate stories remained popular in the subsequent nineteenth century, as novels like Robert Louis Stevenson's Treasure Island demonstrate. In the twentieth and twenty-first centuries, Hollywood has largely replaced memoirs and novels, and actors from Douglas Fairbanks to Errol Flynn to Johnny Depp have starred as pirates in action films that have been hugely successful at the box office. Rediker is certainly correct in claiming that pirates "captured the good ship Popular

45 A. H. John, "The London Assurance Company and the Marine Insurance Market of the Eighteenth Century," Economica XXV (1958), 126-141; see also H. A. L. Cockerell and Edwin Green, The British Insurance Business, 1547-1970: An Introduction and Guide to Historical Records in the United Kingdom (London, 1976), 4-5.

46 John, "The London Assurance Company," Economica XXV (1958), 126-130; Davis, Rise of the English Shipping Industry, 88, 318, 376-377; Barry Supple, The Royal Exchange Assurance: A History of British Insurance, 1720-1970 (Cambridge, 1970), chap. 1-3, 6-80.

47 Swanson, Predators and Prizes, 190-194.

48 Percy G. Adams, "Introduction," to John Esquemeling, The Buccaneers of America ... (1684; repr., New York, 1967), x. See also Jan Rogoziński, Pirates! Brigands, Buccaneers, and Privateers in Fact, Fiction, and Legend (New York, 1995), 117, and Hanna, "The Pirate Nest," 343-348. 
Imagination, and three hundred years later they show no sign of surrendering it." ${ }^{49}$

Pirates have also attracted much attention in South Carolina because of their association with the colony's tangled politics. The golden age of piracy coincided with a particularly volatile period in the political history of North and South Carolina. A group of well connected Englishmen, the Lords Proprietors, owned both provinces. Important politicians in South Carolina believed that the proprietors had failed to provide the Carolinas with adequate economic support. They were especially concerned with the exorbitant costs of defending South Carolina against possible incursions from the Spanish in St. Augustine, Florida, and the French, who had recently built Fort Toulouse near what is now Montgomery, Alabama. In addition, both Carolinas sustained heavy casualties and extensive property damage in two devastating conflicts with native Americans - the Tuscarora War, 1711-1713, and the Yamasee War, 1715-1717. South Carolina was still reeling from the impact of these wars when the pirates began their assault on the province's Atlantic commerce. ${ }^{50}$

The furor caused by the sloop Betty in 1716 reveals that much of the interest surrounding pirates has resulted from their political, as opposed to their economic, importance. Provincial politicians often quarreled with each other, and many influential Carolinians opposed the Lords Proprietors' control of the colony. Incidents involving piracy were intertwined with these political conflicts.

Pirate Captain Benjamin Hornigold, who helped launch Blackbeard's piratical career, captured the Betty from the Spanish, which he then apparently gave to a Captain Perrin from Virginia. ${ }^{51}$ Captain Halhew (Mathew?) Husson, who held a commission to

49 Rediker, Villains of All Nations, 175. Cordingly also offers thoughtful comments concerning the pirates' cultural popularity with perceptive observations concerning books and films in Under the Black Flag. Hanna, "The Pirate Nest," offers a long, thoughtful discussion of pirates and popular culture in which he argues that the image of pirates changed from being compared favorably to Drake, Raleigh, and other English heroes to being portrayed as violent murderers. While persuasive in many ways, Hanna's failure to acknowledge that "golden age" pirates differed significantly from buccaneers in their motivation and willingness to capture English ships weakens his interpretation. Henry Morgan was different from Blackbeard and Ned Low. In addition, even when the media portrayed pirates as murderous villains, the reading public still had a voracious appetite for books about piracy. The public's fascination with pirates extends, of course, far beyond books and films. Numerous professional, college, and high school sports teams adopt their names from pirates, including East Carolina University, where the author of this essay is employed.

50 The best account of these tangled politics is M. Eugene Sirmans, Colonial South Carolina: A Political History, 1663-1763 (Chapel Hill, NC, 1966), 103-128. For a fascinating discussion of South Carolina's geopolitical position in North America during the period 1670-1717, which includes a view of the Lords Proprietors' political problems, see Alan Gallay, The Indian Slave Trade: The Rise of the English Empire in the American South, 1670-1717 (New Haven, CT, 2002). Robert M. Weir's Colonial South Carolina: A History (Millwood, NY, 1983), 75-103, also provides a succinct account of these events.

51 The sources are vague as to how Perrin acquired the Betty. BPRO-SC, VI, 190-234, contains numerous and often conflicting sworn statements and warrants from South Carolina's vice- 
capture pirates, encountered the Betty en route to the Bahamas and seized the sloop. The Betty proceeded to Charles Town and tied up at Gibbon's Bridge (wharf) on 4 July 1716. Then things really got interesting.

Initially, the Betty's sailors refused to let Colonel William Rhett on board. Among his many pursuits, Rhett was the surveyor and comptroller of customs and he tried to board the sloop to secure the cargo and safeguard the king's customs revenue. After informing Deputy Governor Robert Daniel of his intent to board the Betty, Rhett, accompanied by Captain Howard, commander of HMS Shoreham, and an armed detachment of the Shoreham's crew, returned to the sloop and forced open its hatches.

While Rhett, Howard, and their men unloaded the Betty's cargo and placed goods in their long boat and pinnace, Daniel apparently experienced second thoughts about Rhett's actions. Daniel later testified in the inquiry concerning the Betty that he had told Rhett not to unload any cargo until the provincial vice-admiralty court had determined its rightful ownership. Daniel thought that Rhett had accepted this decision. ${ }^{52}$ Rhett had other ideas, however.

One of the most colorful residents in early eighteenth-century Charles Town, Rhett had a fascinating career. He worked as a merchant but also held numerous South Carolina leadership positions. He served as the Lords Proprietors' receiver general, and as already mentioned, he was the crown's surveyor and comptroller of customs. He also won election to the Commons House of Assembly and served as its speaker. He was a militia officer and rose to the rank of lieutenant general. He had also commanded the provincial fleet that repelled the 1706 French and Spanish invasion forces during Queen Anne's War and he captured Stede Bonnet, the notorious pirate. ${ }^{53}$ Clearly, Rhett was used to giving orders, not taking them.

He was also aggressive and accustomed to speaking his mind. A particularly revealing example of his self-assertiveness appeared in a letter from the Lords Proprietors. It seems that Rhett had argued bitterly with Governor Charles Craven in 1713. When Craven showed Rhett his governor's commission from the Lords Proprietors in an effort to overawe him, the colonel was singularly unimpressed: "This is but a Lords proprietors Government," Rhett commented, "\& I wou'd wipe my Arse with the Commission." 54 The proprietors were understandably upset with Rhett's defiant actions and unflattering language, but they did not remove him from office. Rhett continued to argue with and criticize governors after the crown took over South Carolina. In October 1722, Rhett was convicted of "Scandalous words at his Excellency the Governor" and paid a fine of $£ 400$ South Carolina currency, because he had asserted that royal Governor

admiralty court concerning the Betty affair. For Hornigold's early association with Blackbeard, see Johnson, A General History of the Pyrates, 70. Rediker comments about Hornigold's prominent place in golden age piracy in Villains of All Nations, 80-81. Examination of Robert Daniel, 14 July 1716, BPRO-SC, VI, 218.

53 For a brief biographical sketch, see Walter B. Edgar and N. Louise Bailey, eds., Biographical Directory of the South Carolina House of Representatives. Volume II, The Commons House of Assembly, 1692-1775 (Columbia, SC, 1977), 554-556.

54 Lords Proprietors to Rhett, 31 January 1713, BPRO-SC, VI, 50. 
Francis Nicholson was a smuggler. ${ }^{55}$

Nicholson thought Rhett exerted an enormously unsettling influence on South Carolina's public life. He was clearly a dishonest customs officer, Nicholson believed, but more than that, he was a disruptive political agitator: "I hope there is no person who has the honor to bear any Comicon [commission] from ye Comiconrs. [commissioners] of his Majty. Customs [who] are Guilty of the hundredth part of what he is in relation to the Customs. He is a haughty Proud Insolent fellow \& a Cheating Scoundril ... The Man has been always factious and Mutinous in this Governmt. As well under the Proprietors as his Matys." 56 In addition to irritating proprietary and royal governors with his blunt speech, violating his duties as a customs collector, and disrupting politics, Rhett may also have been trading illegally with the Spanish at St. Augustine. Although never convicted of any wrongdoing, Rhett faced accusations of selling arms to the Spanish along with Captain Hildersley, commander of HMS Flamborough. ${ }^{57}$ Rhett vehemently denied the charge, but the South Carolina Council and its London agents thought he was guilty. ${ }^{58}$ An antagonistic and bold individual, Rhett demonstrated his characteristically aggressive behavior in his interactions with Deputy Governor Johnson during the Betty affair.

When Johnson saw that Rhett, Howard, and their men were unloading the Betty, contrary to his orders, the deputy governor ordered the alarm to be sounded, called out the militia, raised the flags at Granville Bastion, and ordered the battery's guns to fire on the Shoreham's boats. Daniel then stormed off to Gibbon's Bridge with Attorney General George Rodd in tow to confront Rhett, Howard, and their men. Daniel and Rodd claimed that Rhett tried to assault Daniel when the deputy governor told him to stop unloading the Betty's cargo. In fact, Captain Howard was forced to restrain Rhett, who shouted, "I will kill the old Rogue let me goe God damn me if I will kill the Dogg!" 59 In the event, Rhett did not attack Daniel; instead he grabbed a heavy iron shovel, struck Rodd a series of blows, and only stopped when Rodd brandished his sword in self-defense. ${ }^{60}$

This incident featured additional death threats uttered by imperial officials and demonstrates how piracy played into provincial politics. Lieutenant James Fellows of HMS Shoreham became embroiled in a conflict with Deputy Governor Daniel that resulted in the lieutenant's incarceration. Fellows had prevented Daniel from boarding the Shoreham on 4 July by pointing a musket at the governor. Of course, from Fellows's perspective, he was only doing his duty:

55 Ibid., X, 14-20.

56 Nicholson to Charles de Lafay, 16 October 1722, ibid., IX, 147.

57 William Popple to Josiah Burchett, 17 Nov. 1720, and Popple to Charles Carkesse, 17 November 1720, ibid., VIII, 233, 242-243. Popple wrote to Burchett because of Captain Hildersley's alleged involvement. Carkesse was the secretary to the customs commissioners. SC Council to Joseph Boone, 19 January 1721, and Rhett to Customs Commissioners, 21 December 1719, transmitted to SC Council by Joseph Boone, SC Agent, 8 October 1720, ibid., IX, 4-7.

59 Examination of Robert Daniel, 14 July 1716, ibid., VI, 221.

60 Examination of George Rodd, 14 July 1716; Examination of Robert Daniel, 14 July 1716, ibid., VI, 194-197; 217-222. 
I was under no small concerne and Passion to see my Captain in His Majts. Boat with the Deputy Survyr. Of the Customs in his Boat (with their Colours flying in Securing his Majts. Interest in the Customes) fired at, it moved me very much, but when I saw them fire at his Majts. Ship and heard the Shot strike the Ship under my Feet as I stood upon the Gunnell and seeing the Governour leading his Men to attack me in the Ship raised me to the greatest Pitch, for this last part seemed to me to be in fact attacking his Sacred Majts in his Person, (whom God preserve and keep from all dangers and Enemys)[. $]^{61}$

A week later, Daniel ordered Fellows placed in irons after he attacked Joseph Swaddle, one of the governor's supporters. During the melee on 4 July, Swaddle had attempted to shoot at the Shoreham's boat, but his weapon misfired. Fellows encountered Swaddle on 11 July in a Charles Town residence. Tempers flared, and blows followed. Daniel, who was present, recognized Fellows as the man who had pointed a musket in his face and ordered him confined. Captain Howard asked for Fellows's release, but Daniel refused. The lieutenant finally won his freedom after obtaining a writ of habeas corpus, posting bail for good behavior, and promising to return for trial. ${ }^{62}$

Fellows's statement reveals how piracy (the notorious pirate Captain Hornigold, Blackbeard's associate, had set this ball rolling when he took the Betty) exacerbated conflicts in provincial politics. Fellows testified that Deputy Governor Daniel and Attorney General Rodd had tried to dupe South Carolina's legislature by blaming Captain Howard's men for the recent tumult. ${ }^{63}$ Fellows believed there was only one solution to South Carolina's scandalous political conduct: King George must take "this Colony into his own hands." ${ }^{" 64}$

Lieutenant Fellows was not the only person in South Carolina who advocated royal government because of the Lords Proprietors' inability to combat piracy. The South Carolina Council and Commons House of Assembly took the drastic step of repudiating the proprietary government and calling for King George to establish South Carolina as a royal colony. In a letter to the Board of Trade in late 1719, the provincial legislators asserted that the colony's defenseless state "forced us as the only Means for our Preservation to Renounce all Obedience to the Lords and to throw our Selves at the foot of the Throne of his most Sacred Majesty King George, humbly Imploring him that he will be pleased to take us unto his Immediate Protection and Government." ${ }^{65}$ In justifying this drastic and possibly traitorous action, the House and Council cited "the Vast Expence We have been at in Subduing the Pyrates for the Defence of Trade,"66 which had left the province defenseless.

61 Examination of Lieutenant James Fellows, 19 July 1716, ibid., VI, 224-225.

62 Ibid., VI, 225-226.

63 Examination of Lieutenant James Fellows, 3 August 1716, ibid., VI, 233.

64 Ibid., VI, 234.

65 SC Council and Commons House of Assembly to the Board of Trade, 24 December 1719, ibid., VI, 223.

66 SC Council and Commons House of Assembly to the Board of Trade, 24 December 1719, ibid., VII, 224. 
The legislators followed their letter to the Board of Trade with a petition to the king in early 1720. Again, they claimed that the Lords Proprietors had shirked their responsibility for the colony. Not only did they fail to provide for the province's defense against piracy, their appointed officials in North Carolina actually helped Blackbeard and his crew to profit from their crimes. The House and Council charged that Blackbeard sailed directly to North Carolina after plundering Charles Town and "by the Connivance of the Proprietors Governr. there comitted Several acts of Pyracy there in the very face of that Governmt. And Several parcels of Pyratical Goods were found in their Governours and Secretarys Custody in Soe much that their Government of North Carolina became a nest of Pyrates." Only the timely intervention of forces dispatched by Virginia Lieutenant Governor Spotswood, the chief executive of a royal colony, prevented the pirates from making further captures. ${ }^{67}$ Once again, Blackbeard and his piratical actions became the center of attention in London and in Charles Town because of their intersection with provincial politics.

Blackbeard's dealings with North Carolina officials suggest that there may have been some truth behind the 1720 South Carolina petition. North Carolina Governor Charles Eden and the colony's secretary and collector of customs, Tobias Knight, knew and entertained the famous pirate after he moved to Bath, North Carolina, in 1718. Governor Eden offered Blackbeard the king's pardon. After killing Blackbeard at Ocracoke, Royal Navy Lieutenant Maynard and his men searched the pirate's vessel: "In rummaging the Pyrate's Sloop, they found several Letters and written Papers, which discovered the Correspondence betwixt Governor Eden, the Secretary and Collector, and also some Traders at New-York, and Black-beard." ${ }^{68}$ These letters intimated that Eden and Knight received part of a sugar cargo that Blackbeard had piratically seized from a French merchantman. A subsequent search of Knight's barn in Bath turned up a substantial amount of sugar. Knight resigned from public office and subsequently faced trial before the colony's council. Although he successfully defended himself from charges that he was an accessory to the pirates, his vindication was short-lived. Knight died from a lingering illness two weeks after the trial. ${ }^{69}$

Captain Johnson's A General History of the Pyrates viewed Governor Eden as being clearly in league with Blackbeard: "The first Piece of Service this kind Governor did to Black-Beard, was, to give him a Right to the Vessel which he had taken, when he was a pyrating in the great Ship called the Queen Ann's Revenge." indicated that most of the illegally seized French sugar wound up in the governor's possession. Yet, unlike Knight, Eden was never tried for his relationship to Blackbeard and continued to serve the Lords Proprietors as North Carolina's governor until his death

67 Petition of the SC Council and Commons House of Assembly to King George I, 3 February 1720, ibid., VII, 291.

68 Johnson, A General History of the Pyrates, 85.

69 For the charges against Knight and his vindication, see Robert J. Cain, ed., Records of the Executive Council, 1664-1734. Vol. 7 of The Colonial Records of North Carolina [2nd ser.] (Raleigh, NC, 1984), 79-99; Butler, Pirates, Privateers, and Rebel Raiders, 46-49. 
in 1722. Eden's chief accusers, Edward Moseley and Maurice Moore, were also his bitter political opponents. Eden was able to discredit the charges against him by claiming they were politically motivated. In fact, he had Moseley and Moore indicted on charges of sedition of which they were convicted and fined. ${ }^{71}$ Although Eden was never convicted of complicity with the pirates that swarmed off North Carolina's coast, his actions conspicuously lacked the aggressive initiative that South Carolina's and Virginia's authorities adopted toward the threat.

Interestingly, Robert Johnson, the Lords Proprietors' governor, did not dispute the South Carolina legislators' claims concerning the colony's inadequate defenses. Even though he cast aspersions on the politicians' motivations for advocating the end of proprietary government (he thought this was a plot led by "Severall of the Richest Inhabitants"), he admitted the province was broke. In fact, Johnson claimed that he had personally lost money by using his own funds to defend South Carolina from pirate attack. "I have this to Ad, That the poor Proffits of the Government at the best, the present poor Sircumstances of the Province, The Extraordinary Expence I was at In Suppressing Severall Pyrates, ... I am a Thousand Pounds Sterling worse by having ever had it [i.e., the governorship]." ${ }^{, 72}$ Johnson's statement reveals that the legislators' charges that the Lords Proprietors neglected the colony had merit. At any rate, it is easy to see how both sides used the threat of piracy in provincial politics.

Of course, other problems besides piracy plagued the Lords Proprietors' government. South Carolina barely survived a disastrous Indian war against the Yamasees and their Creek allies. ${ }^{73}$ In fact, Captain Johnson made the connection between the Yamasee War and South Carolina's weak defenses. He believed that Blackbeard's 1718 appearance caught Charles Town residents unawares because the colony was recovering from this devastating conflict: "What made these Misfortunes [i.e., Blackbeard's depredations] heavier to them was a long expensive War, the Colony had had with the Natives, which was but just ended when these Robbers infested them."74 High casualties, extensive property destruction, low morale, and an empty provincial treasury caused by the Yamasee War may also explain the dramatically weaker response

71 William S. Price Jr., ed., North Carolina Higher-Court Minutes, 1709-1723. Vol. 5 of The Colonial Records of North Carolina [2nd ser.]. (Raleigh, NC, 1974), 198-201, 208-209. Butler believes that Eden's problems stemmed from his lack of military or police power to subdue Blackbeard and that Eden was thus forced "to endure in silence" Blackbeard's outrageous actions; see Pirates, Privateers, and Rebel Raiders, 48-49. Johnson to the Board of Trade, 27 December 1719, ibid., VII, 229.

73 There are numerous letters, reports, and petitions concerning this conflict in ibid., 7. Gallay offers the best secondary account concerning South Carolina's interactions with the area's Indians; see The Indian Slave Trade, chap. 12, 315-344, for the Yamasee War. Sirmans provides a thoughtful account of the political battle between the Lords Proprietors and the colony's legislators; see Colonial South Carolina, 111-117. Gary B. Nash offers an interpretation of Indian-white conflict that is very sympathetic to the Yamasees, Creeks, Tuscaroras, and other native Americans. See Red, White, and Black: The Peoples of Early America, 5th ed. (Upper Saddle River, NJ, 2006), 116-122. 
to Blackbeard's forces compared to the earlier successful reaction to the larger and more powerful French and Spanish invasion attempt of 1706. In addition, to the pirate and Indian threat, many South Carolina leaders feared expansion by the French from Mobile and the Spanish from St. Augustine. South Carolina officials had earlier informed London administrators of their belief that the French and Spanish were aiding the Yamasees and their allies in their war against South Carolina. ${ }^{75}$ Eventually, these complaints against the Lords Proprietors prompted the Lords Justices in Council in London to recommend that the crown take over South Carolina's government. The Board of Trade drew up a draft of instructions for the new royal governor on 16 August 1720, and King George appointed Francis Nicholson to serve as the province's new chief executive the same day. ${ }^{76}$ While piracy's economic impact is difficult to measure, the pirates clearly exerted a marked effect on South Carolina politics.

Pirates seized merchantmen engaged in South Carolina's transatlantic commerce, closed the port of Charles Town, and even boldly walked the city's streets with impunity while the governor and Council debated their response to a ransom demand issued by the era's most notorious pirate captain. In addition to Blackbeard, some of the most famous pirates of the golden age operated off the Carolina coast. Yet piracy did not seriously damage Charles Town's transatlantic commerce. The number of vessels captured and the duration of piratical depredations were far more limited than contemporary accounts suggest. The pirates also missed the busiest shipping season. In addition, South Carolina's naval forces hunted down and eliminated pirates, while similar operations mounted by Virginia also enjoyed success. The Yamasee War that preceded the pirates caused greater loss of life and economic damage. Certainly Blackbeard, Stede Bonnet, Charles Vane, Ned Low, and the others were uncommonly bold in their aggression, yet the prominence they achieved was at least partly explained by the interplay of piracy with provincial politics in early eighteenth-century Carolina. Interests opposed to the Lord Proprietors' government made effective use of the pirates' actions in calling for the imposition of royal government. Cultural values explain the long-term interest in piracy. Pirates attracted the imagination of the eighteenth-century public, as the success of Captain Johnson's books attest. They still do today. Similarly, the bold actions of a man like Colonel William Rhett, though a pirate adversary, also grab attention. He is easily the most colorful person mentioned in the South Carolina governors' correspondence during the early $1700 \mathrm{~s}$. Because of their flamboyant appeal and political ramifications, "golden age" pirates have received much more attention than their economic impact on Carolina commerce merits.

75 See, for example, Benjamin Godin, Ralph Izard, and Edward Hyme to the Board of Trade?, 6 August 1716, and affidavit of SC Deputy Governor Daniel, 13 August 1716, BPRO-SC, VI, 235-243 and 244. Gallay, The Indian Slave Trade, provides the most in-depth discussion of geopolitics concerning the British, French, Spanish, and Indians in southeastern North America.

76 Lords Justices in Council at Whitehall, 11 August 1720, Board of Trade to the Lords Justices, 16 August 1720, Commission and Instructions for Francis Nicholson, 16 August 1720, BPRO-SC, VIII, 36-57. 


\section{Table 1: Vessels Lost to Pirates on the Carolina Coast}

\begin{tabular}{|c|c|c|c|}
\hline Year & Pirate Commander & Prize \& Master & Prize Disposition \\
\hline 1717 & Blackbeard $^{a}$ & Ship & Plundered \& Let Go \\
\hline 1717 & Blackbeard $^{\mathrm{b}}$ & 2 Inbound Vessels & Unknown \\
\hline 1717 & Bonnet $^{a}$ & Sloop Mary & Destroyed \\
\hline 1717 & Bonnet $^{a}$ & Brig Elizabeth ${ }^{\mathrm{e}}$ & Plundered \& Let Go \\
\hline 1718 & Blackbeard ${ }^{c}$ & Ship Crawley ${ }^{\mathrm{e}}$ & Plundered \& Let Go \\
\hline 1718 & Blackbeard $^{a}$ & 2 Inbound Pinks ${ }^{d}$ & Plundered \& Let Go \\
\hline 1718 & Blackbeard $^{a}$ & Brig Inbound & Plundered \& Let Go \\
\hline 1718 & Vane $^{a}$ & Ship, Capt. Coggershall & Plundered \& Let Go \\
\hline 1718 & Vane $^{a}$ & Ship, Robert Cock & Plundered \& Let Go \\
\hline 1718 & Vane $^{a}$ & Sloop Dove & Plundered \& Let Go \\
\hline 1718 & Vane $^{a}$ & Sloop, Capt. Richards & Plundered \& Let Go \\
\hline 1718 & Vane $^{a}$ & Brig Dorothy & Surrendered Intact ${ }^{\mathrm{f}}$ \\
\hline 1718 & Vane $^{a}$ & Ship Outbound & Plundered \& Let Go \\
\hline 1718 & Vane $^{a}$ & Ship Outbound & Unknown \\
\hline 1718 & Worley ${ }^{c}$ & Several Ships & Unknown $^{\mathrm{g}}$ \\
\hline 1719 & Rackham $^{\mathrm{a}}$ & Ship Outbound & Retaken $^{\mathrm{h}}$ \\
\hline 1722 & Lowthera & Ship, Capt. Gwatkins & Pirates defeated ${ }^{i}$ \\
\hline 1723 & Low $^{\mathrm{a}}$ & Ship Crown & Plundered \& Let $\mathrm{Go}^{\mathrm{j}}$ \\
\hline 1723 & Low $^{a}$ & Ship King William & Plundered \& Let $\mathrm{Go}^{\mathrm{j}}$ \\
\hline 1723 & Low $^{a}$ & Ship Carteret & Plundered \& Let $\mathrm{Go}^{\mathrm{j}}$ \\
\hline 1723 & Low $^{a}$ & Outbound Brig & Plundered \& Let $\mathrm{Go}^{\mathrm{j}}$ \\
\hline 1723 & Low $^{\mathrm{a}}$ & 2 Outbound Brigs & Plundered \& Let $\mathrm{Go}^{\mathrm{j}}$ \\
\hline Totals & & 23 Vessels plus "several" others & \\
\hline
\end{tabular}

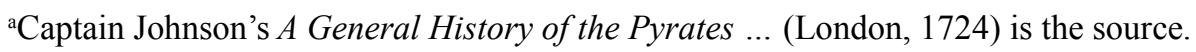

${ }^{b}$ Records in the British Public Record Office Relating to South Carolina, 1663-1782 (BPRO-SC) is the source.

'Referred to in Johnson's A General History of the Pyrates and BPRO-SC. fishing.

${ }^{\mathrm{d} A}$ A pink was a small square-rigged coastal vessel with a square stern, frequently used for

eSouth Carolina Naval Officer Shipping Lists, 1716-1767, from Charles Town, National Archives of Great Britain, London, Colonial Office, 5/508-511 (microfilm) contains additional 
information concerning these vessels.

fVane released the vessel, while his consort, Capt. Yeats, returned the cargo to South Carolina authorities and accepted the king's amnesty, thus retiring from piracy.

gSince S. C. Governor Robert Johnson killed Captain Worley and many of his crew, the authorities may have recaptured these prizes.

${ }^{\mathrm{h}}$ Captain Woodes Rogers, governor of the Bahamas, dispatched an armed sloop that recaptured this ship. This prize was bound to England from Charles Town when Rackham captured it near Bermuda.

'Captain Gwatkins's vessel was not lost to the pirates. In fact, the Amy nearly captured Lowther's pirate ship and crew.

jJohnson's A General History of the Pyrates does not discuss this prize's fate, but this is the mostly likely outcome.

Table 2: Percent of Vessels Entering and Clearing Charles Town by Month

\begin{tabular}{|l|l|l|}
\hline Season \& Month & $\mathbf{1 7 1 7 - 1 7 7 5}$ & $\mathbf{1 7 1 7 - 7 1 9}$ \\
\hline Winter & $\mathbf{3 1 . 9}$ & $\mathbf{2 3}$ \\
\hline December & 9.2 & 5.9 \\
\hline January & 12 & 8 \\
\hline February & 10.7 & 9.1 \\
\hline Spring & $\mathbf{2 9 . 2}$ & $\mathbf{3 4 . 9}$ \\
\hline March & 11 & 12.3 \\
\hline April & 9.2 & 10.3 \\
\hline May & 9 & 12.3 \\
\hline Summer & $\mathbf{2 0 . 7}$ & $\mathbf{2 6 . 3}$ \\
\hline June & 8 & 10.8 \\
\hline July & 6.8 & 8.4 \\
\hline August & 5.9 & 7.1 \\
\hline Fall & $\mathbf{1 8}$ & $\mathbf{1 5 . 7}$ \\
\hline September & 5.1 & 5.9 \\
\hline October & 5.9 & 4.9 \\
\hline November & 7 & 4.9 \\
\hline Total Voyages & $\mathbf{2 8 1 5 6}$ & $\mathbf{8 2 0}$ \\
\hline
\end{tabular}

Sources: South Carolina Naval Office Shipping Lists, National Archives of Great Britain, London, Colonial Office, 5/508-511 (microfilm), and South-Carolina Gazette (Charles Town). Although the NOSL are nearly complete for 1717-1719, they are very sparse for the early 1720 s, and the Gazette did not begin publishing until 1732. 